Philosophy and Progress: Vols. LIII-LIV, January-June, July-December, 2013 ISSN 1607-2278 (Print), DOI : http://dx.doi.org/10.3329/pp.v53i1-2.21950

\section{A VIOLENT THREAT TO CONSERVATION OF WETLANDS AND THE EXISTING LAWS OF BANGLADESH: A CRITICAL ANALYSIS}

\section{Tahmina Haq ${ }^{*}$}

\begin{abstract}
In Bangladesh, wetlands are nursing areas for fresh water species. The freshwater wetlands have been considered an inexhaustible source of its wealth, but are now overexploited and undervalued. Sound wetlands could contribute to a healthy and sustainable economic condition. The focal point of this article is to conserve natural resources with special attention to the freshwater wetlands. Even the ponds or reservoirs under the private ownership except certain circumstances would come within the term 'conservation of wetlands', though the personal rights and enjoyments are being hampered. Therefore, the wetlands should be utilized for welfare of the people by protecting those from ruination and preserving biodiversity through proper and time-befitting work plans. Moreover, the article contains a broad discussion of current laws regarding the conservation of wetlands. But very unfortunately, there is no specific provision of law for the sustainability of such wetlands, but to declare ecologically critical area while in a vulnerable situation.
\end{abstract}

\footnotetext{
${ }^{*}$ Lecturer, Dept. of Law \& Justice, Bangladesh University of Business \& Technology, (BUBT), Dhaka. Email : tahmina.cu@gmail.com
}

\section{Introduction}

Wetlands are very important and very rich natural resources in terms of biodiversity and ecological system. The total area of Wetlands in Bangladesh is about seven or eight million hectares, which constitutes about $50 \%$ of the land surface of the country. Bangladesh floodplains are one of the world's most important wetlands, harboring hundreds of species of fish, plants and wildlife. The wetlands in Bangladesh encompass a wide verity of dynamic ecosystems ranging from mangrove forest (about 577, 100 ha), natural lakes, man-made reservoir (Kaptai lake), freshwater marshes (about 400 haors), oxbow lakes (about 54488 ha, locally known as baors), freshwater depressions (about 1,000 beels), fish ponds and tanks (about 147, 000 ha), estuaries and seasonal inundated extensive floodplains. ${ }^{1}$ The direct or indirect threats which have been dominating over the Wetlands of Bangladesh are multifarious and directly related to the socio-economic condition of the local people and successive changes in the ecosystems. The haors, baors, beels and jheels are of fluvial origin and are commonly identified as freshwater wetlands. The manmade wetlands include the ditches, ponds, tanks, lakes or reservoirs. Now wetlands are dried up regularly for agricultural lands, residential purpose and setting up of Industries.

\section{Meaning of Wetlands}

Degradation of wetlands has caused several problems including extinction and reduction of wildlife, extinction of many indigenous wild and domesticated rice varieties, loss of many indigenous aquatic plants, herbs, shrubs and weeds, loss of natural soil nutrients, loss of natural water reservoirs and of their resultant benefits, increase in the occurrence of flooding and degeneration of wetland based ecosystems, occupations, 
socio-economic institutions and cultures. The Ramsar Convention on wetland in 1971, in Iran characterized wetlands as

“... areas of marsh, fen, peatland, whether natural or artificial, permanent or temporary, with water that is static or flowing, fresh, brackish or salt, including areas of marine water the depth of which at low tide does not exceed six meters." ${ }^{2}$

Although the general definition given above applies around the world, each county and region tends to have its own definition for legal purposes. Wetlands are defined under various Acts of Bangladesh given below:

According to The Bangladesh Environment Conservation Act, 1995 (as amended to 2010) ${ }^{3}$, “Ecosystem” means the inter-dependent and balanced complex association of all components of the environment which can support and influence the conservation and growth of all living organisms. Again in the said Act 'Water Body' has been defined as river, canal, haor, deep tank, and pond, fountain or water reservoir.

More or less above mentioned Acts inserted the importance of the conservation of wetlands as defined to maintain the ecological balance.

Article 18A of The Bangladesh Constitution in its fifteenth amendment made provisions for conservation and development of the environment and biodiversity. Before that the Constitution remained silent about the preservation of biodiversity. But the High Court Division in a renowned PIL case explained the provision with regard to safety of life. In the case of Dr. Mohiuddin Farooque Vs Bangladesh and Others in $1996^{4}$, the High Court Division accepted the argument presented by the petitioner that the constitutional 'right to life' does extend to include 'right to a safe and healthy environment'. Article 31 and 32 of our Constitution protect right to life as a fundamental right. It encompasses within its ambit, the protection and preservation of environment, ecological balance free from pollution of air and water, sanitation without which life can hardly be enjoyed. Any act or omission contrary thereto will volatile of the said right to life.

\section{Impacts of Degradation of Wetlands}

We are affected by climate change adaption in Bangladesh. The rapid expansion of roads and house building by filling the wetlands, and narrowing the riverside even in the rural areas is tremendously changing the traditional look of our rural environment. The temptation of urbanization has surprising impact upon the rural life which caused the ecology endangered. Even the decentralization of administration at the Upazilla (sub-district) level is responsible for this change.

Degradation of wetlands on Bangladesh has created the following negative impacts:

1. Extinction and reduction of fish habitat, fish population and diversity;

2. Loss of indigenous aquatic plants, weeds and shrubs;

3. Deterioration of living conditions; and

4. Loss of natural nutrients and natural water reservoirs. ${ }^{5}$

Nishat pointed out that the degradation of wetlands in Bangladesh were mainly due to increase of population and expansion of human habitats; expansion of agriculture and subsequent conversion of wetlands through drainage into rice fields; flood control and irrigation project for enhancement of agricultural productivity; national, local and rural infrastructures like ill-planed roads; narrow culvert etc.; overfelling of wetland trees; over-grazing by livestock; over-fishing 
and associated disturbances; siltation due to degradation of watershed areas which are often transboundary in nature; indiscriminate control/ regulation / use of water flows of main river systems in upper riparian; and pollution of water due to industrial, urban, agrichemical and other types of pollutants including pollution from transboundary sources ${ }^{6}$.

\section{Measures taken by the Government of Bangladesh}

The institutions developed so far for the propagation of the spirit, education and expatriation for protecting, managing and utilizing our Wetlands are negligible. But, a few Govt. and Non-Govt. institutions have been playing a considerable role in this concern. Govt. institutions like - the Ministry of Land, Ministry of Environment and Forests, Govt. Forest Dept. and Fisheries Dept., BD Water Development Board (BWDB), Flood Plain Co-ordination Organization (FPCO), The Space Research and Remote Sensing Organization and a few NGOs are playing a vital role in the conservation of our Wetlands. For ensuring healthy wetlands GO, NGO and different level of people should work together. But, ironically, no specific legislation for the management and monitoring of wetlands prevails in the country.

Rajshahi City Corporation (RCC) has planned to conserve 53 natural water-bodies in the city in order to retain its surface water resources for protecting the environment from further degradation. The city corporation has adopted a Taka 206.24crore uplift project titled "Natural Water Bodies Conservation and Development in Rajshahi City" to attain the cherished goal side by side with protecting the ponds from further dumping. There were 729 ponds and canals in the metropolis in 2002, but the figure declined to 393 at present due to indiscriminate earth-dumping and unplanned urbanization. Due to abnormal declining of surface water, he said dependence on groundwater has been increasing for ensuring of supply water to the city dwellers causing unusual lowering groundwater table for the last couple of years. The situation becomes worse during the dry season leaving most of the hand-driven tube-wells inoperative. (BSS).

\section{Case Laws}

In BELA Vs Ministry of Land and others (2003), the High Court Division asked for special protective measures to protect and conserve the 4916 hectares of Sonadia Island as ecologically critical area (ECA) with an object to save the people living thereby from being inundated and swept by tidal bore during natural disasters. In another case of BELA Vs Bangladesh and others (2004), the High Court Division seeks protective measures to conserve the 9285.15 sq. kilometers of the Sundarbans as ecologically critical area with a view to protect the forest and habitat of wild animals.

In another PIL case of Dr. Mohiuddin Farooque $v$. Bangladesh \& others, Writ Petition No. 7422/1997 (Gulshan Lake Fill-up), a division bench of the High Court Division issued a Rule in a petition filed in 1997 against implementation of an agreement called the "Banani, Gulshan, Baridhara Lake Development Project Agreement” signed between RAJUK and Indus Valley Investment Pvt. Ltd. to undertake a huge construction in the said areas, defying and violating the constitutional and legal requirements. The Court directed them to show cause as to why "the agreement and the subsequent agreements to lease out a total area of 220 acres of public land should not be declared to have been entered/undertaken without lawful authority in violation of law and the constitution against public interest and as such be declared null and void and of no legal effect." The Government subsequently cancelled the project. 


\section{Provisions of Law}

1971 Ramsar Convention : The Convention's mission is the conservation and wise use of wetlands by national action and international cooperation as a means to achieving sustainable development throughout the world. Methods enshrined in this Convention include restricting access to the majority portion of wetland areas, as well as educating the public to combat the misconception that wetlands are wastelands. Bangladesh has ratified the 1971 Ramsar Convention (Convention on Wetlands of International Importance, especially as Waterfowl Habitat) and designated two wetlands (Sundarbans and Tanguar Haor), which has strengthened conservation efforts there (and led to Tanguar being taken out of commercial leasing). The Convention addresses to protect the threatened wetlands, to improve resources, to conserve and enhance the wetlands.

\section{The Tanks Improvement Act, 1939}

The Tanks Improvement Act is a milestone in respect of agricultural development and environment in Bangladesh. This is because, the fallow tank or disused agricultural land are taken into consideration for the purpose of agriculture and irrigation in the country. Most of them are private ownership. These tanks are mostly remained vacant or useless because of the different problematic situations like ownership, grouping etc. However, the Government of Bangladesh enacted this law addressing those problems and also ensuring the rural economy of Bangladesh. For ensuring and sustainable use of this tank, the Tank Improvement Act is enacted in 1939 and its objectives are to provide for the improvement of tanks for purposes of irrigation and pisciculture. 'Tank' means a reservoir or place which has been used as the storage of water whether formed by excavation, or by the construction of one or more. This is the only Act which violates the personal rights and enjoyments, but only for the purpose of agriculture. The sole object is to protect agriculture while the Act ignores the conservation of the natural ecosystems and bio-diversities of that area. Again there is no provision of conservation of natural resources in This Act. In fact, the provision of acquisition of fallow tanks by the Government is a violation of personal rights and ownership which also can be done for the protection of ecological balance ${ }^{7}$.

\section{The Bangladesh Environmental Conservation Act (1995)}

The Bangladesh Environmental Conservation Act (1995) established the Department of Environment (DoE) and specifies a move towards ecosystem approaches and regulation of developments harmful to those ecosystems, particularly pollution control and mitigation and requirements for Environmental Impact Assessments. The Act includes provisions for declaring Ecologically Critical Areas (ECAs) to restrict potentially harmful activities in these areas. The Act recognizes the Polluter pays principle as it puts the provision of compensation.

Section 5 (sub-section 1\&2) of The Environment Conservation Act, 1995 states that if any area is threatened to reach an environmentally critical condition then the Government may declare it as ecologically critical area (ECA) through Gazette notification which has already made clear under section 2 of the Bangladesh Environment Conservation Rules, 1997.

Section 6E of The Environment Conservation (Amendment) Act, 2010 mentions as follows: Notwithstanding anything contained in any other law for the time being in force, a marked off place not fill up which is known as reservoir of 
water and shall not allow any sort of alteration to this respect: Provided that, restriction regarding reservoir of water may be relaxed by receiving of clearance certificate from said department for indispensable national importance.

Section 7 of The Environment Conservation Act, 1995 empowers the Director General to compensate for injurious measures to ecosystem.

Section 15 of The Environment Conservation (Amendment) Act, 2010 imposes penalty for the violation of section $6 \mathrm{E}$ which extends to 2 to 10 years and compensation not exceeding 10 lac taka or both.

Restrictions are imposed not to fill up wetlands, but the clearance certificate may relax them. Again, in this Act, no term specifically stands for a water body which might be filled up by its owner. Another problem lies with the Act which does not provide any preventive measures ${ }^{8}$. The well recognized Precautionary principle has not been accepted to take prior steps before declared as an ecologically critical area.

\section{The Environment Court Act, 2010}

The Environment Court ${ }^{9}$ enjoys the exclusive jurisdiction for trial of an offence or for compensation falling under the Environment conservation Act and other environmental laws. But in practice, a few complainants faced court procedure due to insufficient environment courts and lack of knowledge about the courts. The Act was silent about preventive or remedial measures to avoid probable injury to environment and wetlands as well. Any other law to be dealt with by the Environment Court is not declared yet except The Environment Conservation Act.

\section{The Water Act, 2013}

Another important Act named as Bangladesh Water Act, 2013 has been made for the improvement, management, collection, distribution, usage, protection and preservation of the water. The Act recognizes the significance for managing all forms of water resources in the context of natural flow of surface water and recharge of groundwater. The private landowners will be able to use the surface water inside their property for all purposes in accordance with the Act. No individuals or organizations will be allowed to extract, distribute, use, develop, protect, and conserve water resources, nor will they be allowed to build any structure that would impede the natural flow of rivers and creeks.

Conservation of wetlands as grazing ground and sanctuary of the migratory birds has been given much importance while conservation of ponds as a source of pure drinking water in critical areas has been abandoned. But this is unfortunate that the Act recognizes the significance for managing all forms of water resources in the context of natural flow of surface water and recharge of groundwater rather making a commitment by the government to ensure the quality of water for various beneficial uses. The lack of clear directives that will facilitate recovery of the flood flow zone by evicting land grabbers and encroachers remains as a serious weakness of the Act. The Act specifically mentions that rights over surface water on any private land shall remain with the owner of such land. But the executive committee can issue a protection order to the owner of such private land without discrimination for the protection and conservation specially to prevent the wastage and misuse of water $^{10}$. Conservation of ponds is included as a clause within section 22 of The Water Act as 'Conservation of water source and management thereof' which bears no importance. As a result the sole public demand in the critically water scarce 
areas remains mixed up with the issue of conservation of water bodies as the sanctuary and grazing ground of the migratory birds $^{11}$. Nishat, a former Professor of the Bangladesh University of Engineering and Technology, said in the coming years it would be a big challenge to provide water to industries and cooling towers of power generation projects, including the proposed nuclear power plant in Ruppur ${ }^{12}$.

Again, the Protection and Conservation of Fish Act, 1950, and related Protection and Conservation of Fish Rules, 1985, which cover not only fish but also amphibians and aquatic reptiles, prohibit fishing by harmful methods, pollution and other activities detrimental to fisheries, and enable declaration of closed seasons and other rules. More recently, the Conservation, Restoration and Filling Control Act of 2003 aims to address problems of siltation, encroachment and pollution of surface waters (rivers, canals, floodplains) as well as aquifers. However, this Act puts emphasis especially on the protection of fish which is quite clear that a non-fishing water body is not its concern.

\section{Environmental Policies}

The National Environment Policy, (1992) maintains the ecological balance, water development and pollution free wetlands which results to the Environment Conservation Act 1995.

The Environment Action Plan (1992) covers to take steps to establish an agricultural system based on local ecosystem.

The National Fisheries Strategy and Inland Capture Fisheries Strategy (2006) set out a framework for community management of inland fisheries based on leasing at nominal rates, widespread conservation measures, and precautionary development of aquaculture in floodplains.
The Jalmohal Management Policy (2009) allows for fisher organizations to lease water bodies without competitive bidding, and mentions sanctuaries and swamp forest.

The importance in the above instruments merely goes for the wetlands for fisheries, agriculture and the resources over there. But the importance of keeping water bodies on earth is very much helpful for the ecological balance. The priority goes for the sustaining wetlands rather filling up useless wetlands.

Bangladesh wetlands support a significant range of other activities such as extraction of reed, harvesting of edible aquatic vegetation and other products. Wetlands are unique for their rich bio-diversity and cultural heritage and more significantly retaining the ecological balance for the environment ${ }^{13}$. Our rural ecosystems especially the ponds and the reservoirs provide a scope for livelihoods particularly for fishing, vegetables, and pasture for cattle. Wetlands are one of the most productive and resourceful areas, which help us for cultivating crops, fishing etc. About 50\% rural people are directly dependent on agriculture for their livelihoods and many others indirectly depend on agriculture input and crops marketing activities in wetland areas. Wetlands are vital ecosystems that provide livelihoods for the millions of people who live in and around them. The Millenium Development Goals (MDGs) called for different sectors to join forces to secure wetland environments in the context of sustainable development and improving human wellbeing.

\section{Conclusion}

The loss of wetlands is threatening to imbalance the whole environment as well as the frequent filling of ponds and reservoirs is affecting the very ability to sustain the wetland habitats. Though the conservation of wetlands demands the 
prior care of ensuring a healthy environment, appropriate policies must be taken to ensure a sustainable conservation of wetlands. Public awareness must be developed for wetland conservation. Not only the 'khas ponds' are to be conserved, but also the man made ponds or reservoirs under personal ownership can be conserved with proper care as the conservation of 'khas ponds' will not be sufficient for ecological balance.

The first step in developing wetland management was intensive community consultations to identify local wetland threats and develop a consensus on solutions in the form of participatory action plans. The second step was to establish the institutional framework for communities and local government to co-manage the wetlands on their door ships. Three types of institutions were created at village, wetland and local government levels, as well as one union level federation ${ }^{14}$.

According to Rajshahi Development Authority (RDA), there were 4,238 ponds, canals, wetlands in 1961, 2,271 wetlands in 1981, the numbers were 729 in 2000 and now the city has only 214 water bodies. The only concern stands for Rajshahi because of the symptoms of desertification over there, where the issue of conserving water bodies is gradually becoming a national problem. So it can be easily understood that the number of 'khas ponds' is very poor in Bangladesh. The water bodies even under personal ownership should come within this struggle of conservation. Freshwater wetlands must sustain to overcome the water crisis. But the common phenomenon is that wetlands and bio-diversity as well are reducing day by day. To avoid this situation national policies can be adopted, thereafter the Acts must contain such mandatory provisions of sustainable development of wetlands. If the wetlands are lost or dried, the whole agriculture and the ecological balance will be endangered. It is better to conserve the wetlands before these are getting worse, not before making them worsen.

\section{References}

1. Ainun Nishat (1993) 'Freshwater Wetlands in Bangladesh: Status and Issues", in Freshwater Wetlands in Bangladesh: Issues and Approaches for Management,' Ainun Nishat et al (eds), IUCN- The World Conservation Union, Dhaka Bangladesh.

2. http://www.ramsar.org, 20 December, 2013.

3. The Environment Conservation Act, 1995\& Rules 1997.

4. Dr. Mohiuddin Farooque Vs. Bangladesh and Others, 48DLR, 1996, p. 438.

5. M. Salar Khan, Emanul Huq, Saleemul Huq, A Atiq Rahman, SMA Rashid and Helal Ahmed, 1994, Wetlands of Bangladesh, published by Bangladesh centre for Advanced Studies (BCAS) Dhaka, Bangladesh.

6. Nishat, 1993, 'Freshwater Wetlands in Bangladesh'

7. The Tanks Improvement Act, 1939.

8. Section 5 of The Conservation Act, 1995 (as amended up to 2010).

9. The Environment Court (Amendment) Act, 2010.

10. Section 3 of the Water Act, 2013.

11. Section 22 of the Water Act, 2013.

12. Nishat, 2011, Environment victim of poor law enforcement, Dhaka Mirror, June 2.

13. Mizanur Rahman Bhuiyan, December4, 2013, Wetland Management in Bangladesh.

14. Md. Mijanur Rahman and Anwara Begum (2010), The Strategy of Empowering Poor for Wetland Resources Conservation in Bangladesh. 